\title{
Mercado das Drogas Ilícitas e Homicídios no Brasil: Um Estudo Comparativo das Cidades de Belo Horizonte (MG) e Maceió (AL)
}

\author{
Luís Flávio Sapori \\ Doutor em Sociologia e professor do programa de pós-graduação em ciências sociais da Pontifícia \\ Universidade Católica de Minas Gerais (PUC Minas). Belo Horizonte, MG, Brasil. \\ E-mail: flaviosapori@gmail.com. ORCID: https:/ / orcid.org/0000-0002-3398-7249 \\ INTRODUÇÃO
}

\begin{abstract}
A elevada incidência de homicídios na sociedade brasileira a posiciona entre as mais violentas do mundo. Esse fenômeno tem sido objeto preferencial de estudos entre os especialistas do tema nas últimas décadas. Dispomos de diagnósticos precisos sobre sua dinâmica temporal bem como espacial. Já sabemos que a taxa de homicídios no Brasil manifesta tendência de crescimento desde a segunda metade da década de 1980, apresentando relativa estabilidade nos anos 2000 e voltando a crescer em anos posteriores. Até o final dos anos 1990 a Região Sudeste capitaneou esse processo de deterioração da violência urbana, sendo sucedida pelos estados do Norte e Nordeste. O recrudescimento da violência não se restringiu às grandes cidades e regiões metropolitanas. Cidades de pequeno e médio porte sofreram também com o crescimento da incidência de homicídios desde o início dos anos 2000. (Cerqueira et al, 2017; Waiselfisz, 2016; Cardia, Adorno e Poleto, 2003; Nobrega Jr, 2016).
\end{abstract}

Acumulamos conhecimento, ainda, sobre o perfil social das vítimas dessa violência ascendente. São preferencialmente jovens na faixa etária de 15 a 24 anos e do gênero masculino. Seu viés racial não suscita mais dúvidas, atingindo em boa medida os jovens negros. Os homicídios não se distribuem de forma homogênea no espaço urbano. Sua incidência é maior nas regiões mais pobres, caracterizadas por altos níveis de vulnerabilidade social (Soares, 2008; Cano, 2001; Peres et al, 2011). 
A despeito desse respeitável acervo de conhecimento adquirido mediante pesquisas consistentes, ainda persistem questões não respondidas. A principal delas diz respeito às motivações dos homicídios. Ainda há controvérsia quanto à dimensão do impacto do mercado das drogas ilícitas na incidência desse crime no Brasil. Governadores, secretários de segurança pública e lideranças policiais, de modo geral, são categóricos na afirmação de que o tráfico de drogas é responsável por mais de $70 \%$ dos assassinatos dos jovens negros das periferias urbanas ${ }^{1}$. Há, por outro lado, contraposições acadêmicas bastante consistentes quanto à tese da correlação estrita entre o mercado das drogas e homicídios.

Esse artigo pretende oferecer contribuição a esse debate. Resulta de pesquisa ${ }^{2}$ realizada em Belo Horizonte (MG) e Maceió (AL), tendo a seguinte questão: em qual magnitude os conflitos gerados no âmbito do mercado das drogas ilícitas são responsáveis pelos homicídios ocorridos nessas cidades?

Do ponto de vista metodológico, foram consultados os relatórios finais dos inquéritos policiais de homicídios com autoria identificada nas respectivas cidades nos anos de 2012 e 2013. Procedeu-se ao estabelecimento de uma tipologia de conflitos, que orientou a categorização de cada homicídio investigado no período. A partir desses procedimentos foi possível identificar a participação percentual de cada uma das motivações no total de homicídios esclarecidos pela polícia em cada cidade.

A principal descoberta da pesquisa reside na constatação estatística de que o mercado das drogas ilícitas é, de fato, motivação relevante dos homicídios analisados em ambas as cidades, porém não impacta a maior parte do fenômeno. É possível supor, inclusive, que a magnitude dessa motivação seja maior do que a encontrada na pesquisa. Como dito, a base de dados consultada foi o relatório final de inquéritos com autoria identificada, o que representa parte pequena do total de homicídios efetivamente ocorridos. Tanto em Belo Horizonte (MG) quanto em Maceió (AL), mais de $80 \%$ dos homicídios registrados no biênio 2012-2013 não tiveram os respectivos inquéritos policiais finalizados com identificação de autoria. Pesquisa recente realizada por Misse (2010) confirma que a maioria dos homicídios esclarecidos são aqueles que já chegam ao conhecimento da polícia com a autoria identificada, especialmente flagrantes realizados pela Polícia Militar. 
Brigas de bar, crimes passionais, disputas entre familiares e vizinhos acabam tendo uma participação superdimensionada como motivação dos crimes esclarecidos, pois são casos que já chegam elucidados à polícia, ao contrário do que ocorre com os homicídios relacionados ao tráfico

Além disso, a pesquisa identificou número expressivo de homicídios cuja motivação não era relacionada à dinâmica do mercado das drogas ilícitas, mas nos quais os autores tinham envolvimento com essa atividade. Caracterizei esse fenômeno como difusão da violência pelo mercado das drogas ilícitas.

\section{O DEBATE TEÓRICO SOBRE O TEMA}

O impacto das drogas ilícitas sobre a criminalidade é objeto de reflexão há quatro décadas, constituindo importante vertente teórica no âmbito da criminologia (Tonry e Wilson, 1990; Blumstein, 1995; Johnson,Golup e Dunlap, 2000; Wilson e Petersilia, 2011).

Essa relação foi objeto de sistematização conceitual em artigo referencial de Goldstein (1985), que formulou uma categorização tripartite. Segundo o autor, os homicídios decorrentes do consumo e do comércio de drogas podem ocorrer em três contextos distintos:

a) efeitos psicofarmacológicos das drogas, de modo que após a ingestão da droga, alguns indivíduos podem se tornar "irracionais" ao ponto de agirem de forma violenta. A violência psicofarmacológica pode resultar também da irritabilidade associada a síndromes de substâncias que causam dependência química. Além disso, o uso da droga pode contribuir para que o indivíduo se comporte violentamente, como também pode alterar seu comportamento de tal maneira a aumentar seus riscos de vitimização;

b) formação de compulsão econômica, que deve ser compreendida como o potencial que a dependência da droga tem na incidência de crimes contra o patrimônio. Alguns usuários de drogas cometem roubos e furtos para obterem recursos econômicos necessários ao financiamento do consumo contumaz. Em diversas situações, onde há reação das vítimas, ou descontrole emocional do criminoso, podem ocorrer homicídios; 
c) violência sistêmica, que está relacionada à dinâmica do comércio das drogas, especialmente as drogas ilícitas. Incluem-se aqui disputas territoriais entre traficantes rivais, afirmação de códigos de condutas no interior dos grupos de traficantes, eliminação de informantes, punições por adulteração de drogas, punições por dívidas não pagas, entre outros conflitos que emergem no processo de comercialização do produto.

A dimensão sistêmica da relação entre drogas e violência é a que tem obtido as principais evidências empíricas nos estudos internacionais sobre o tema. Ela direciona a atenção para a conformação de um mercado que transaciona produtos considerados ilegais, o que o define como um mercado também ilegal. As trocas efetivadas em seu âmbito não estão amparadas pelas instituições do Estado, de modo que os desacordos e conflitos que emergem em sua dinâmica tendem a ser resolvidos pelo uso ou ameaça do uso da força física. $\mathrm{O}$ uso das armas de fogo torna-se corriqueiro entre traficantes como estratégia de afirmação de reputação perante concorrentes e clientes. $\mathrm{O}$ cometimento de homicídios tende a se manifestar como recurso de resolução de conflitos e consequente afirmação de poder nesse tipo de mercado ilegal (Boyum et al, 2011).

Essa perspectiva analítica que concebe a violência como aspecto constitutivo da ilicitude do mercado das drogas tem sido também contemplada, em maior ou menor grau, por diversos cientistas sociais brasileiros em suas respectivas produções acadêmicas. Não constitui novidade, portanto, afirmar que parte da violência urbana na sociedade brasileira está associada ao tráfico de drogas.

A partir da década de 1980, pesquisadores como Alba Zaluar e Michel Misse realizaram trabalhos empíricos referenciais sobre os mecanismos sociais associados ao mercado ilegal de drogas, a participação da juventude residente em territórios de alta vulnerabilidade social e a atuação repressiva da polícia sobre esse mercado. Merece menção também as contribuições de Gláucio Soares, Silvia Ramos, Ignácio Cano, Luiz Eduardo Soares, Daniel Cerqueira, Carolina Grillo, Luiz Antônio Machado da Silva, entre outros. A rica e variada produção científica dessa intelligentsia carioca acabou por conformar e pautar a interpretação da dinâmica do tráfico de drogas na sociedade brasileira, influenciando pesquisas em outros centros acadêmicos. 
Desde as primeiras publicações, Alba Zaluar (Zaluar 1985; 1994; 2004; 2012) argumenta que o aumento da violência observado na cidade do Rio de Janeiro - na virada da década de 1970 para a década seguinte - estava associado ao aparecimento e à difusão de um novo estilo de traficar cocaína que trouxe a arma de fogo como meio de defender a mercadoria e o ponto de venda. Os conflitos armados entre as facções criminosas estavam relacionados a disputas entre competidores econômicos por territórios. A ilegalidade desse "crime-negócio", como ela denomina, explicaria em boa medida o empoderamento de organizações criminosas envolvidas na continuidade da atividade econômica, que incluiria redes de fornecedores no atacado e vendedores no varejo. Esse é o contexto social no qual se inserem os jovens negros e pobres residentes nesses territórios, e que se tornam protagonistas da violência interpessoal. Imbuídos de um "etos guerreiro" e de um estilo de masculinidade peculiar, caracterizado como hipermasculinidade, os jovens impõem uma dominação local marcada pelo poder das armas e pela ostentação do dinheiro.

Michel Misse (Misse, 1999; 2006; 2007) também considera a dimensão da ilegalidade do mercado das drogas em suas análises sobre a violência no Rio de Janeiro (RJ). A despeito de sua crítica ao conceito de crime organizado, reconhece que os patamares da violência na cidade recrudesceram no processo de consolidação das quadrilhas de traficantes nas favelas e conjuntos habitacionais. O lucrativo e expansivo mercado da cocaína é que fomentou as guerras entre tais grupos, com a entrada maciça de crianças e adolescentes nesse comércio ilegal. O que singulariza a análise de Misse é o argumento de que parte importante da violência associada ao tráfico de drogas envolve a participação direta de agentes do Estado em particular, policiais. Esses fornecem de armamentos aos traficantes e negociam outros tipos de mercadorias informais tais como propinas, chantagens, extorsões e redes de proteção. São as denominadas mercadorias políticas. A confluência desses mercados ilegais acentua ainda mais os homicídios. Portanto, não é uma violência derivada apenas do tráfico de drogas. A sobreposição de dois mercados ilegais, sendo um que oferece drogas ilícitas e outro que o extorque impondo a troca de mercadorias políticas, constitui um dos eixos do que Misse denominou acumulação social da violência na cidade do Rio de Janeiro. 
Deve-se considerar também a relevante produção de Carolina Grillo (Grillo, 2008; 2013; 2016), que concebe o mercado de drogas ilícitas como um grande conjunto de redes que engloba diferentes modos de atuação no mercado, como também diferentes dinâmicas de violência. Ela qualifica o "tráfico de drogas da pista" e o "tráfico de drogas do morro". No primeiro tipo de rede, o comércio das drogas é praticado principalmente por jovens de classe média, operado através de relações pulverizadas, sem uma demarcação territorial reconhecível e caracterizado por uma postura de encobrimento das atividades ilícitas. O emprego da violência é evitado e condenado nessa vertente do tráfico. Na rede do morro, por seu turno, aposta-se na visibilidade para facilitar a identificação dos pontos de venda pelos consumidores. A dimensão territorial ganha uma enorme importância, de modo que os traficantes passam a disputar os territórios para a venda entre si, e ainda precisam defendê-los da polícia. É bastante óbvia a relação da territorialidade desse tráfico com a demanda pelas armas e consequente solução violenta de conflitos

O impacto do comércio das drogas ilícitas na incidência de homicídios também tem sido analisado por estudiosos paulistas, destacando-se Vera Telles, Daniel Hirata e Gabriel Feltran (Telles e Hirata, 2007; Feltran, 2010). O que os caracteriza é a proposta de compreender as dinâmicas urbanas atuais a partir das configurações dos mercados ilícitos. Assim como Misse, evitam utilizar a categoria crime organizado para analisar o tráfico de drogas,preferem indicar suas capilaridades no mundo social e nas tramas urbanas, principalmente nos bairros periféricos da cidade de São Paulo (SP). Não observam apenas o tráfico de drogas, como também as diversas manifestações de ilegalidades que estão presentes na circulação de riquezas no cotidiano de uma grande metrópole. Estão imbuídos, portanto, da perspectiva de compreender como os indivíduos transitam entre os diversos mercados legais e ilegais, consolidando tramas sociais. Importante desdobramento dessa perspectiva de análise é a constatação empírica de que o tráfico de drogas conseguiu se impor como parâmetro de regulação da ordem pública nas periferias da cidade de São Paulo (SP). Passou a atuar como instância normativa, regulando os diversos conflitos cotidianos das comunidades onde atuam. Esse fato ajuda a explicar a redução expressiva dos homicídios em São Paulo (SP) na década passada, dada a monopolização do varejo do mercado das drogas ilícitas mediante 
a supremacia do Primeiro Comando da Capital (PCC). Instituiu-se uma moralidade própria nas periferias da cidade, caracterizada pela restrição do uso da violência na resolução dos conflitos do tráfico.

A produção acadêmica mineira sobre o tema é outra a merecer destaque. Estão na linha de frente dos estudos sobre a dinâmica violenta do tráfico de drogas em Belo Horizonte (MG) os pesquisadores Cláudio Beato, Felipe Zilli, Bráulio Figueiredo, Rafael Rocha, Ludmila Ribeiro, Andréa Silveira, todos vinculados ao Centro de Estudos de Criminalidade e Segurança Pública da Universidade Federal de Minas Gerais (CRISP/UFMG). O que tem notabilizado os pesquisadores do CRISP é a constatação de que as manchas de concentração de homicídios tentados e consumados em Belo Horizonte (MG) seguem praticamente o mesmo padrão de distribuição geográfica das favelas e dos assentamentos irregulares. Há uma concentração socioespacial demarcada que evidencia a relação que os homicídios registrados em Belo Horizonte (MG) mantêm com processos de urbanização desordenada, segregação espacial, exclusão social e dinâmicas de violência perpassadas por gangues juvenis. Estas estão distribuídas de maneira extremamente fragmentada, com vários coletivos de jovens delinquentes ocupando simultaneamente pequenas frações de diferentes favelas. A coexistência de grupos diferentes dentro de um mesmo espaço aumenta significativamente o potencial de conflitos entre eles, seja por problemas pessoais entre membros dessas gangues, por questões de estabelecimento de território e consolidação de poder local, ou disputas envolvendo dinâmicas criminais - como é o caso do tráfico de drogas. Não existe uma lógica necessariamente econômica e racional norteando a estruturação de atividades criminosas entre gangues. (Beato et al, 2001; Zilli e Beato, 2015; Rocha, 2015).

Distinguindo-me um pouco da abordagem dos pesquisadores do CRISP, tenho enfatizado a prevalência da racionalidade econômica dos homicídios cometidos no contexto do tráfico de drogas em Belo Horizonte (MG) (Sapori e Medeiros, 2010; Sapori, Lamounier e Silva, 2012; Sapori e Soares, 2014). São especialmente as disputas territoriais, os acertos de contas e as cobranças de dívidas que motivam em boa medida a violência interpessoal na dinâmica do comércio ilegal das drogas. Destaco, inclusive, como a introdução do crack nesse mercado potencializou a violência na capital mineira a partir de meados da década de 1990. E isso ocorreu não pelos efeitos farmacológicos do crack, que supostamente engendraria dependentes químicos agressivos. Na verdade, os efeitos farmacológicos do 
crack tendem a criar certos tipos de usuários bastante compulsivos e mais propensos a acumular dívidas com seus fornecedores. E, nesse mercado, a não quitação da dívida pode implicar em morte. Além disso, usuários compulsivos do crack são contumazes em dar "derrame da droga", ou seja, com frequência passam a ser vendedores da droga como forma de pagamento pelo que recebem de fornecedores. $O$ problema é que muitos acabam consumindo as pedras que deveriam ser revendidas, caracterizando o "derrame", tornando-os vulneráveis a retaliações, incluindo homicídios por parte de traficantes.

No que se refere aos demais centros acadêmicos do país, merecem menção os estudos que José Luiz Ratton vem realizando em Pernambuco (Ratton e Daudelin, 2017). Ratton tem se dedicado recentemente a compreender o mercado de drogas em Recife (PE). Sua análise reforça a perspectiva da violência sistêmica desse mercado ilícito. Porém, evidencia que a probabilidade de ocorrência da violência depende das situações desse mercados. Nesse sentido, diferencia mercados cobertos e mercados descobertos. Um mercado descoberto envolve trocas físicas que são públicas e visíveis, e como resultado disso, baseadas em um espaço determinado, criando um ambiente inerentemente inseguro. Essa insegurança se deve a eventuais disputas territoriais com competidores tentados a conquistar os espaços físicos onde as transações ocorrem. Ademais, assaltantes sabem que compradores com dinheiro e vendedores com produtos convergem para os mesmos espaços. Transações cobertas, por contraste, têm lugar em espaços privados e bem protegidos ou mesmo em ambientes virtuais. De fato, os mercados mais cobertos têm como base a internet e são aqueles que vendem drogas mais potentes, em grande volume, e com elevada discrição. A paz que reina nos mercados de classe média, de acordo com as evidências levantadas por seu estudo, está associada em grande medida ao fato desses mercados serem fechados e cobertos, ao contrário do que predomina nos mercados de crack, abertos e descobertos, o que os torna vulneráveis à violência.

Esse levantamento da produção teórica e empírica em nosso país acerca da relação entre drogas e violência evidencia certo consenso entorno da compreensão de que parte dos elevados patamares de homicídios nos centros urbanos são explicados pela dinâmica do mercado ilegal das drogas. Persiste, contudo, a dúvida quanto à magnitude e ao contexto dessa relação. Esses estudos ainda não conseguiram quantificar o quão impactante são os homicídios derivados do mercado ilícito das drogas 
no total de homicídios registrados. Para tanto, é imprescindível diagnosticar as motivações dos homicídios ocorridos, distinguindo aqueles que estão relacionados ao mercado das drogas ilícitas dos homicídios que resultam de conflitos outros. Eis a questão a ser explorada adiante. A explicitação das motivações dos homicídios exige a explicitação dos conflitos que estão em sua gênese.

\section{DIMENSÃO SITUACIONAL DO HOMICÍDIO}

Do ponto de vista sociológico, homicídio é o ato de tirar a vida de uma das partes inseridas numa situação de conflito. Envolve necessariamente uma interação social que por algum motivo culmina em discordância, separação e desarmonia. Seu fundamento, portanto, é o antagonismo entre indivíduos e a resolução do antagonismo passa pelo uso da violência física. Em outros termos, o homicídio é um dos desfechos possíveis de conflitos nas relações sociais. Como nos lembra Simmel, "o conflito está assim destinado a resolver dualismos divergentes; é um modo de conseguir algum tipo de unidade, ainda que através da aniquilação de uma das partes envolvidas" (Simmel, 1983: 122). Averiguar a motivação de homicídios implica na identificação das circunstâncias que engendraram o conflito entre autor e vítima. Exige a reconstituição de tramas e eventos que levaram ao antagonismo na relação social, considerando as dimensões do tempo e do espaço.

Tal abordagem coaduna-se com a perspectiva analítica proposta por Miethe e Regoeczi (2004), que focaliza a dimensão situacional dos homicídios. Segundo esses estudiosos, os homicídios são fenômenos complexos que não podem ser compreendidos apenas pelas dimensões macroestruturais. Técnicas estatísticas multivariadas têm sido utilizadas para estudos das eventuais correlações entre taxas de homicídios e variáveis socioeconômicas, tanto longitudinais quanto cross-sectional. A despeito da relevância desses estudos, deve-se reconhecer a limitação deles na compreensão das situações dos homicídios. Estas, por si só, constituem importante unidade de análise.

As situações dos homicídios envolvem combinações diversas de autores, vítimas e circunstâncias. Implica considerar gênero, raça e idade de autor e vítima, a motivação subjacente ao ato, o tipo de relacionamento existente entre autor e vítima, o número de vítimas e autores, 
tipo de arma usada e o contexto físico do fato. A diversidade dessas situações de homicídios pode ser quantificada mediante a classificação de atributos particulares associados ao ato criminal.

Em suma, esta pesquisa parte da premissa teórica de que as situações de homicídios englobam tanto estrutura quanto processo. A estrutura é definida pela combinação particular de atributos do autor, da vítima e do contexto social do homicídio. O processo, por sua vez, incorpora a dinâmica relacional do fenômeno, as características do conflito e consequente motivação do homicídio. Em outras palavras, a devida compreensão do fenômeno exige a explicitação dos contextos nos quais essas mortes ocorreram, ou seja, o tipo de conflito, seu significado para as partes envolvidas, seu objeto e sua estruturação (Costa, 2011).

\section{INQUÉRITO POLICIAL COMO BASE DE DADOS}

O desafio que se apresenta a um estudo que pretende explicitar as características dos conflitos geradores dos homicídios é a base de dados a ser consultada. Trata-se de ter acesso a relatos dos eventos que culminaram no homicídio. São quatro as bases de dados oferecidas pelas organizações do sistema de justiça criminal nesse sentido:

1. Os boletins de ocorrência registrados pela Polícia Militar. Estes boletins, além de qualificar as características estruturais do crime, também descrevem brevemente o ocorrido, indicando suas supostas motivações a partir de depoimentos de testemunhas;

2. Os inquéritos finalizados e com autoria do crime identificada que são remetidos ao Ministério Público pela Polícia Civil. Em todo inquérito de homicídio consta como parte final um relato do fato investigado, denominado de relatório final, contendo a descrição do ocorrido, a identificação do autor, e as provas obtidas com a investigação. Dependendo da amplitude das informações obtidas com a investigação, o relatório final pode conter ainda um relato detalhado da relação entre autor e vítima, e das circunstâncias que culminaram na morte da vítima;

3. As denúncias efetivadas pelo Ministério Público. Analisam as evidências de materialidade e autoria presentes nos inquéritos policiais recebidos e decidem por dar início ao processo penal; 
4. Processos finalizados após o julgamento pelo Tribunal do Juri e com trânsito em julgado. Esses processos ficam arquivados nos fóruns das comarcas e apresentam testemunhos e evidências acrescidos ao respectivo inquérito policial durante a fase judicial. Além disso, tais processos finalizados contêm a sentença de condenação ou absolvição do acusado pelo crime.

Há ainda uma quinta alternativa que não envolve relatos produzidos pelos profissionais dos aparatos policial e judicial: os auto-relatos produzidos pelos próprios homicidas que cumprem pena de privação de liberdade. Mediante entrevistas semiestruturadas é possível reconstituir os eventos que culminaram no homicídio cometido pelo entrevistado.

A escolha do presente estudo recaiu sobre os relatos elaborados pelos inquéritos policiais e constantes dos relatórios finais. Para tanto, obteve-se acesso aos relatórios finais de todos os inquéritos finalizados com autoria identificada nos anos de 2012 e 2013 em Belo Horizonte (MG) e Maceió (AL). A seleção desses municípios se deu por motivos estritamente práticos. Por um lado, o autor acumulou larga experiência no estudo da violência em Belo Horizonte (MG), o que facilitou o acesso aos dados de inquéritos policiais da capital mineira. Maceió (AL) também foi contemplada por conta da facilidade de acessos à base de dados, derivada da contratação do autor pela Secretaria Nacional de Segurança Pública (SENASP) para avaliar os resultados do projeto "Brasil Mais Seguro" no estado de Alagoas.

É importante salientar que, no caso de Maceió (AL), esses inquéritos tiveram como responsáveis delegados e investigadores providos pela Força Nacional de Segurança Pública (FNSP), dado que no biênio mencionado o governo federal, através da SENASP, disponibilizou contingente da FNSP para apoiar o governo estadual no patrulhamento ostensivo e na apuração de homicídios em Maceió (AL). Tanto em Belo Horizonte (MG) quanto em Maceió (AL) foi realizado contato com os delegados responsáveis pelas respectivas delegacias especializadas, para os quais foram explicitados os objetivos e metodologia do estudo. Com a devida autorização dessas chefias, obteve-se a cópia dos relatórios finais dos inquéritos de homicídios arquivados em ambas as unidades policiais no biênio 2012-2013. 
Foram consultados 194 relatórios finais de inquéritos de homicídios em Belo Horizonte (MG), e 301 em Maceió (AL). Os inquéritos em ambas as cidades se referem a homicídios ocorridos em sua totalidade no biênio considerado, conforme tabela 1 .

Tabela 1

Distribuição dos Inquéritos Analisados Segundo o Ano de Ocorrência dos Homicídios

\begin{tabular}{lccc}
\hline & 2012 & 2013 & TOTAL \\
\hline Belo Horizonte (MG) & 100 & 94 & 194 \\
Maceió (AL) & 120 & 181 & 301 \\
\hline
\end{tabular}

Fonte: Dados da pesquisa. Elaboração própria.

Em termos de representatividade, os inquéritos analisados correspondem a $12 \%$ dos homicídios registrados oficialmente em Belo Horizonte (MG), e 19\% em Maceió (AL), no biênio 2012 e 2013. O número de ocorrências de homicídios no período foram 1642 em Belo Horizonte (MG), e 1538 em Maceió (AL).

Para a categorização da motivação dos inquéritos dos homicídios selecionados procedeu-se primeiramente à definição de uma tipologia de motivações tomando como base o material empírico disponível. A partir daí fez-se a leitura dos relatórios finais dos inquéritos e, mediante a identificação de características típicas da conflitualidade geradora do homicídio, recorreu-se ao estabelecimento da motivação do respectivo crime. Cada homicídio foi categorizado com apenas um tipo de motivação.

Não se ignora nesse estudo que os inquéritos policiais dizem muito sobre os vieses e modos de operação das polícias, conforme relevante literatura nacional tem evidenciado (Misse, 2011; Kant De Lima, 1994; Vargas, 2007). A despeito dessa limitação, entende-se que as investigações de homicídios realizadas pelos policiais civis, e consolidadas no inquérito, permitem ao pesquisador o acesso a dados e informações relevantes sobre as situações sociais que engendraram o fenômeno. No relatório final é descrita a série de eventos que culminaram no(s) assassinato(s). Há variações entre os inquéritos no grau de detalhamento dos relatos presentes no relatório final. A despeito disso, o pesquisador tem à sua disposição um rico material empírico que permite 
a análise sociológica dos conflitos geradores dos homicídios e, consequentemente, de suas motivações. Coube ao pesquisador analisar os fatos descritos e estabelecer a motivação.

\section{TIPOLOGIA DE MOTIVAÇÕES}

Uma classificação simples das motivações distingue os homicídios instrumentais dos expressivos. Homicídios instrumentais são aqueles conduzidos por objetivos conscientes, tais como adquirir dinheiro, aumentar o poder etc. Já homicídios expressivos não são racionalmente calculados, resultando de manifestações de raiva, inveja, frustração etc.

A despeito de sua relevância, tal classificação não é capaz de identificar as singularidades das circunstâncias dos homicídios. Estabelecer tipos de circunstâncias de homicídios significa reconhecer que existem diversidades que não podem ser negligenciadas naquilo que se denomina de "homicídios instrumentais/expressivos". A caracterização do conflito é imprescindível nesse sentido.

A proposta desse estudo é estabelecer uma tipificação de motivações que considere as características do conflito gerador do fato. $\mathrm{Ou}$, em outras palavras, as circunstâncias do conflito. Os objetivos dos autores dos homicídios não são considerados como parâmetros de distinção, sejam eles econômicos, políticos, religiosos etc. Optou-se por priorizar a identificação de atributos estruturadores de conflitos capazes de agregar objetivos distintos. Entre tais atributos estruturadores destaco a temporalidade do conflito e o contexto da relação entre os envolvidos.

A tipologia elaborada, portanto, não partiu de uma prévia concepção teórica ou mesmo de senso comum. Foi mediante a leitura cuidadosa dos relatórios finais de inquéritos de homicídios que se formulou seis circunstâncias principais de motivações. São elas:

\section{Desentendimento}

Envolve uma situação de conflito na qual autor e vítima se desentendem por questões variadas (desde acidentes de trânsito, passando por divergências de opiniões e até mesmo por desacertos comerciais), que 
resultou em homicídio. Pode ocorrer entre conhecidos e desconhecidos, entre vizinhos, no trânsito, em bares, em situações de lazer e/ou sociabilidade.

A vítima se encontrava em bar onde também estava o agressor. A vítima foi ao bar comparar uma cerveja e um refrigerante e voltou para sua casa, em frente ao bar. Pouco depois, voltou para comprar cigarros. Índio, o agressor, pediu à vítima bebida alcoólica, a vítima negou. Na saída do bar, Índio começou a correr atrás da vítima com uma faca, o golpeou algumas vezes e fugiu. Índio foi indiciado (IP Maceió/ 2012).

\section{Rivalidade}

Envolve uma situação de conflito que se prolonga ao longo do tempo, por dias, meses ou anos, com provocações recíprocas entre as partes via injúrias, agressões verbais e/ou físicas e ameaças. A origem do conflito pode ter matizes diversos, desde divergências entre sócios de um empreendimento econômico, entre vizinhos que não se entendem na definição dos limites das respectivas propriedades, entre familiares que divergem na divisão de uma herança, por exemplo. Envolve indivíduos conhecidos.

A vítima foi morta a tiros em via pública. De acordo com testemunhas a vítima trabalhava no táxi do agressor, porém tomou uma multa e FULANO o despediu por isso. Mas visando o pagamento da multa, o agressor disse que se a vítima pagasse a multa poderia trabalhar novamente com ele. A vítima pagou a multa e pagou uma nova licença de taxista mas o agressor não o aceitou de volta no emprego. Com isso a vítima foi atrás de FULANO em companhia de um amigo para que ele o ressarcisse o dinheiro, mas o agressor não concordou. A vítima tentou agredir FULANO, ele atirou na vítima e fugiu (IP / Bhte /2013).

\section{Vingança}

Envolve uma situação de conflito na qual o autor mata a vítima como revide por uma morte de um ente familiar ou amigo perpetrado pela vítima anteriormente. Pode envolver conhecidos, assim como também desconhecidos. 
A vítima for a um julgamento no Fórum Lafayette e, ao deixar o local, pegou um táxi. Quando entrou no táxi, foi atingida por um disparo de arma de fogo, falecendo no local. O autor assumiu o crime e disse que foi motivado pelo fato de a vitima ter assassinado um primo seu. O autor foi indiciado (IP/Bhte/2012).

\section{Passional}

Envolve uma situação de conflito na qual autor e vítima mantêm ou mantiveram uma relação marital, sexual ou afetiva (namoro, casamento, noivado, amásia etc.) com temporalidades momentâneas ou de longa duração e, em função de ciúme, término do relacionamento, traição ou mesmo em função de desentendimentos constantes entre eles, acaba gerando o assassinato de uma das partes. Estão incluídas aqui as relações homoafetivas. Também são considerados os casos em que a vítima é um terceiro participante da relação, como amante ou um(a) novo(a) parceiro(a).

A vítima morreu em decorrência de um espancamento, realizado por seu marido. O autor diz que chegou em casa tarde, deixando a vitima aborrecida, sem querer deixá-lo entrar. Ele teria forçado a porta, empurrando-a contra o chão. A vítima se trancou no banheiro dizendo que chamaria a polícia. $O$ autor arrombou a porta e espancou a vítima, que ficou muito machucada, mas só recebeu socorro no dia seguinte, quando foi internada em coma, assim permanecendo por um mês e, finalmente, vindo a óbito. A filha do casal, que não presenciou a cena, diz em seu depoimento que o casal tinha um relacionamento turbulento mas não por conta do pai, que era uma pessoa tranquila, e sim da mãe, que agredia o pai e o traía. Depoimentos de vizinhos não confirmam a narrativa da filha do casal. O autor foi indiciado (IP Maceió/2012).

\section{Mercado das drogas ilícitas}

Envolve uma situação de conflito na qual autor e vítima têm sua relação baseada no mercado de drogas ilícitas. Os homicídios abarcados por esta categoria estão relacionados a conflitos oriundos de situação de negócios, tais como disputa por pontos de venda, desentendimentos entre sócios e/ou parceiros, desentendimentos com clientes e fornecedores, rivalidades e cobranças de dívidas. 
A vítima, Isaac, foi assassinada com um golpe de faca no pescoço e morreu no local do crime, um terreno baldio. Segundo testemunhas, incluindo a própria mãe da vítima, Isaac era usuário de crack, morador de rua e já tinha se envolvido em vários crimes, principalmente furtos. Segundo a testemunha Baratinha, que era amigo da vítima, Isaac tinha dívidas com o traficante Nenzinho, assim como a própria testemunha. O traficante Nenzinho disse que matou Isaac e mataria Baratinha também. De acordo com o tio de Nenzinho, o sobrinho era realmente envolvido com drogas, tentou matarBaratinha duas vezes e matou Isaac (IP Maceió /2013).

\section{Ação policial}

Envolve uma situação de conflito na qual o policial mata a vítima no exercício de sua atividade profissional. Aplica-se às Polícias Militar e Civil. Pode envolver indivíduos desconhecidos ou mesmo conhecidos.

A vítima saía de um baile funk acompanhado de 4 amigos que tinham envolvimento em crimes relacionados ao tráfico de drogas, roubos e homicídios. Todos estavam no carro da vítima e, ao passarem por uma rua, se depararam com uma viatura da Polícia Militar. Os policiais, que faziam ronda, tinham o alerta de suspeitos armados nas imediações do local do baile e deram ordem aos ocupantes do carro para que parassem e se submetessem à revista policial. A vitima, que conduzia o carro, tentou fugir e foi seguido pelos policiais que contam, em depoimento, terem avistado uma arma em poder dos suspeitos em fuga. Os policiais efetuaram 8 disparos de pistola, tendo atingido a vítima, causando sua morte e um acidente do veículo (IP Maceió/2012).

Houve casos nos quais as situações de conflitos geradoras dos homicídios não se encaixavam nas categorias estabelecidas, tais como homicídios praticados aleatoriamente por indivíduos com distúrbios mentais, ou em reação a tentativas de assalto. Agrupei essa gama variada de situações na categoria Outras Motivações.

Além disso, um número não desprezível de relatórios finais de inquéritos não esclarece a motivação do fato, a despeito de identificação da autoria. Foram categorizados como Motivação Indefinida.

Merece menção semelhante o esforço de estabelecimento de tipologia de motivação de homicídios realizado por Silva (2008). Os tipos são: a) bala perdida; b) trabalho policial; c) drogas (tráfico; d) motivos 
financeiros; e) vingança; f) motivos amorosos; g) conflitos cotidianos; h) outros não especificados; i) caput/indefinidos. Há nítida aproximação entre a tipologia empregada pela autora e utilizada nesta pesquisa.

\section{SITUAÇÕES DE HOMICÍDIOS EM BELO HORIZONTE (MG)}

A Tabela 2 apresenta a distribuição de vítimas e agressores dos homicídios em Belo Horizonte (MG) por gênero. Nos 194 inquéritos analisados foram registrados 247 agressores e 195 vítimas. Nota-se uma maioria expressiva da participação masculina tanto como autores (92\%) quanto como vítimas (89\%). Mulheres figuram mais como vítimas $(11 \%)$ do que como autoras ( $8 \%)$.

Tabela 2

Perfil de Gênero de Vítimas e Autores de Homicídios - Belo Horizonte (MG)

\begin{tabular}{cccccc}
\hline & \multicolumn{2}{c}{ Feminino } & \multicolumn{2}{c}{ Masculino } & \multirow{2}{*}{ Total } \\
\cline { 2 - 5 } & Frequência & $\%$ & Frequência & $\%$ & \\
\hline Autores & 21 & 8 & 226 & 92 & $247(100 \%)$ \\
Vítimas & 21 & 11 & 174 & 89 & $195(100 \%)$ \\
\hline
\end{tabular}

Fonte: Inquéritos policiais de homicídios com autoria identificada. Elaboração própria.

Armas de fogo são os principais artefatos utilizados nos homicídios analisados, corroborando evidência já diagnosticada em estudos diversos (Cerqueira et al, 2017; Waiselfisz, 2016.) Cerca de 60\% dos homicídios envolveram uso de armas de fogo, sucedidos pelas armas brancas em $8 \%$ dos casos. Outros instrumentos utilizados, tais como pedras, enxadas, venenos e a força física correspondem a $11 \%$ dos homicídios.

Tabela 3

Tipo de Arma Utilizada no Homicídio - Belo Horizonte (MG)

\begin{tabular}{lcc}
\hline & Frequência & $\%$ \\
\hline Arma de Fogo & 116 & 60 \\
Arma Branca & 15 & 8 \\
Outros & 21 & 11 \\
Não Informado & 42 & 21 \\
\hline TOTAL & 194 & 100 \\
\hline Fonte: Inquéritos policias de homić́dios com atora identificada. Elaboraç̃ó própria
\end{tabular}

Fonte: Inquéritos policiais de homicídios com autoria identificada. Elaboração própria. 
No que diz respeito à motivação, os conflitos no mercado das drogas ilícitas representam a principal motivação dos homicídios em Belo Horizonte (MG), atingindo $29 \%$ dos casos. Em segundo lugar aparecem os conflitos entre rivais, que somam $28 \%$ do total. Destaque para as porcentagens expressivas dos conflitos passionais e causados por desentendimentos, que representam, respectivamente, $13 \%$ e $10 \%$ dos casos. Homicídios resultantes da ação policial estão no patamar de $2 \%$, bem abaixo do verificado em outros contextos urbanos brasileiros.

Tabela 4

Motivação dos Homicídios - Belo Horizonte (MG)

\begin{tabular}{lcc}
\hline & N & $\%$ \\
\hline Mercado das drogas ilícitas & 57 & 29 \\
Rivalidade & 54 & 28 \\
Passional & 25 & 13 \\
Desentendimento & 20 & 10 \\
Vingança & 12 & 6 \\
Ação policial & 4 & 2 \\
Outros motivos & 13 & 7 \\
Indefinida & 9 & 5 \\
\hline Total & 194 & 100 \\
\hline Fonte: Inquéritos policiais de homić́dios com autoria identificada. Elaboração própria.
\end{tabular}

Quando se analisa comparativamente a motivação dos homicídios, importantes características do fenômeno são reveladas. A Tabela 5 apresenta o perfil de gênero das vítimas e agressores nos homicídios motivados pelo comércio das drogas ilícitas em comparação a demais motivações agregadas. Merece destaque a constatação de que a participação masculina nos homicídios no âmbito do comércio das drogas ilícitas, seja como autor ou como vítima, é mais proeminente do que nos demais tipos de homicídios. Mais de $90 \%$ dos casos na tipologia comércio de drogas ilícitas envolvem vítimas e agressores do gênero masculino. A participação das mulheres nesses casos é inferior à observada nas demais motivações. A mulher como vítima do homicídio, por exemplo, representa apenas $2 \%$ dos casos, ao passo que a vitimização feminina nas demais motivações chega a $14 \%$. Tais evidências reafirmam a constatação de que no mercado das drogas ilícitas prevalecem homicídios nos quais homens matam outros homens. 
Tabela 5

Perfil de Gênero de Autores e Vítimas de Homicídios por Tipo de Motivação Belo Horizonte (MG)

\begin{tabular}{lcccccccc}
\hline & \multicolumn{3}{c}{$\begin{array}{c}\text { Mercado das drogas } \\
\text { ilícitas }\end{array}$} & \multicolumn{4}{c}{$\begin{array}{c}\text { Demais } \\
\text { motivações }\end{array}$} \\
\hline & \multicolumn{3}{c}{ AUTOR } & \multicolumn{2}{c}{ VITIMA } & \multicolumn{2}{c}{ AUTOR } & \multicolumn{2}{c}{ VÍTIMA } \\
\hline & Frequência & $\%$ & Frequência & $\%$ & Frequência & $\%$ & Frequência & $\%$ \\
Masculino & 77 & 95 & 56 & 98 & 149 & 90 & 118 & 86 \\
Feminino & 4 & 5 & 1 & 2 & 17 & 10 & 20 & 14 \\
\hline Total & 81 & 100 & 57 & 100 & 166 & 100 & 138 & 100 \\
\hline
\end{tabular}

Fonte: Inquéritos policiais de homicídios com autoria identificada. Elaboração própria.

A especificidade do mercado das drogas ilícitas no engendramento de homicídios fica ainda mais destacada quando se analisa comparativamente o tipo de arma utilizada. Armas de fogo estão presentes em $98 \%$ dos casos, sendo que nas demais motivações a sua participação é de $67 \%$, revelando quão decisiva é a utilização desse armamento na imposição da ordem nesse tipo de mercado.

Gráfico 1

Arma Utilizada no Homicídio por tipo de Motivação - Belo Horizonte

Mercado das drogas ilícitas

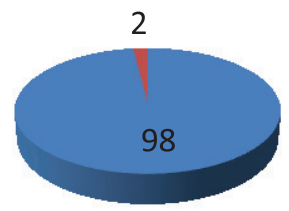

Arma de

Fogo

Outros
Demais motivações

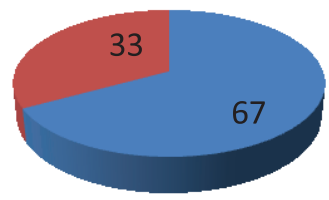

Arma de Fogo

Outros

Fonte: Inquéritos policiais de homicídios com autoria identificada. Elaboração própria.

\section{SITUAÇÕES DE HOMICÍDIOS EM MACEIÓ (AL)}

No município de Maceió (AL) foram analisados 301 inquéritos de homicídios. Diferentemente de Belo Horizonte (MG), obteve-se acesso aos inquéritos em sua integralidade, não se restringindo aos relatórios finais. Nos 301 inquéritos de homicídios analisados foram identificados 596 autores e 306 vítimas. Em termos de gênero, reafirmam a ampla prevalência dos homens como autores em $96 \%$ dos casos, e vítimas em $92 \%$. Merece atenção, entretanto, a constatação de que a magnitude percentual da participação feminina nos homicídios na 
capital mineira difere em relação à capital alagoana. Em Maceió (AL) as mulheres são mais vitimizadas do que em Belo Horizonte (MG), mas a participação feminina como autoras de homicídios também é maior em Belo Horizonte (MG).

Tabela 6

Perfil de Gênero de Autores e Vítimas de Homicídios - Maceió (AL)

\begin{tabular}{lcccc}
\hline & AUTOR & \multicolumn{3}{c}{ VÍTIMA } \\
\hline & frequência & $\%$ & frequência & $\%$ \\
Masculino & 572 & 96 & 282 & 92 \\
Feminino & 24 & 4 & 24 & 8 \\
\hline Total & 596 & 100 & 306 & 100 \\
\hline
\end{tabular}

Fonte: Inquéritos policiais de homicídios com autoria identificada. Elaboração própria.

Armas de fogo estiveram presentes em $82 \%$ dos homicídios, com participação mais modesta de armas brancas, que apareceram em 13\% dos casos. Esse dado está de acordo com evidências compiladas em âmbito nacional.

Tabela 7

Tipo de Arma Utilizada nos Homicídios - Maceió (AL)

\begin{tabular}{lcc}
\hline Tipo de arma & N & $\%$ \\
\hline Arma de Fogo & 245 & 82 \\
Arma Branca & 40 & 13 \\
Outros & 16 & 5 \\
\hline Total & 301 & 100 \\
\hline
\end{tabular}

Fonte: Inquéritos policiais de homicídios com autoria identificada. Elaboração própria.

No que diz respeito às motivações, os conflitos derivados da dinâmica do comércio das drogas ilícitas respondem por $25 \%$ dos casos em Maceió (AL), patamar abaixo do belo-horizontino. É a principal motivação dos homicídios, assim como na capital mineira. Há diferenças não desprezíveis nas magnitudes percentuais entre as duas cidades no que tange às demais motivações, o que sugere singularidades locais que não podem ser negligenciadas. É o caso dos homicídios por conflitos passionais, que em Maceió (AL) correspondem a 7\% do total, ao passo que em Belo Horizonte (MG) atingem 13\%. 
Tabela 8

Motivação dos Homicídios - Maceió (AL)

\begin{tabular}{lll}
\hline & N & $\%$ \\
\hline Mercado das drogas ilícitas & 75 & 25 \\
Rivalidade & 70 & 23 \\
Desentendimento & 41 & 14 \\
Passional & 26 & 9 \\
Vingança & 21 & 7 \\
Ação policial & 4 & 1 \\
Outros motivos & 19 & 6 \\
Indefinida & 45 & 15 \\
\hline Total & 301 & 100 \\
\hline
\end{tabular}

Fonte: Inquéritos policiais de homicídios com autoria identificada. Elaboração própria.

Quando se distingue o perfil de gênero de agressores e vítimas, bem como o tipo de arma utilizada, os dados sobre Maceió (AL) são similares aos de Belo Horizonte (MG). A vitimização e a autoria femininas de homicídios são inferiores no âmbito do mercado das drogas ilícitas. Além disso, a arma de fogo é mais utilizada nesse tipo de motivação comparativamente às demais motivações, situando-se em patamar bastante próximo àquele verificado em Belo Horizonte (MG).

Tabela 9

Perfil de Gênero de Autores e Vítimas de Homicídios por Tipo de Motivação - Maceió (AL)

\begin{tabular}{lcccccccc}
\hline & & \multicolumn{3}{c}{$\begin{array}{c}\text { Mercado das drogas } \\
\text { ilícitas }\end{array}$} & & \multicolumn{3}{c}{$\begin{array}{c}\text { Demais } \\
\text { motivações }\end{array}$} \\
\hline & AUTOR & \multicolumn{2}{c}{ VÍTIMA } & AUTOR & \multicolumn{3}{c}{ VÍTIMA } \\
\hline & Frequência & $\%$ & Frequência & $\%$ & Frequência & $\%$ & Frequência & $\%$ \\
Masculino & 196 & 98 & 74 & 96 & 376 & 95 & 208 & 91 \\
Feminino & 4 & 2 & 3 & 4 & 20 & 5 & 21 & 9 \\
\hline Total & 200 & 100 & 77 & 100 & 396 & 100 & 229 & 100 \\
\hline Fonte: Inquéritos policiais de homicídios com autoria identificada. Elaboração própria.
\end{tabular}


Gráfico 2

Arma Utilizada no Homicídio por Tipo de Motivação - Maceió (AL)

Mercado das drogas ilícitas

Demais motivações

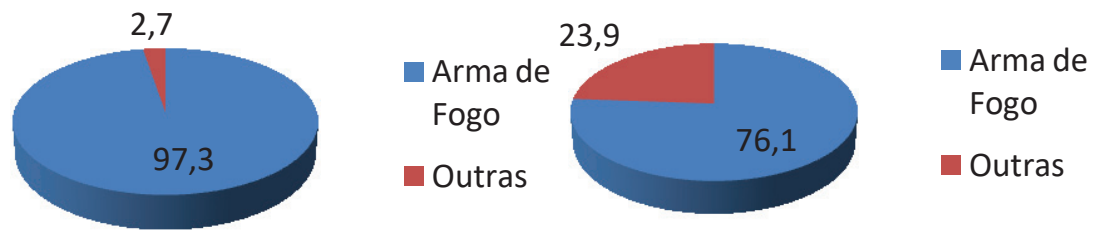

Fonte: Inquéritos policiais de homicídios com autoria identificada. Elaboração própria.

\section{MERCADO DAS DROGAS ILÍCITAS E VIOLÊNCIA SISTÊMICA}

Os dados apresentados revelam que a motivação dos homicídios com a maior participação percentual nas capitais estudadas deriva de conflitos no mercado das drogas ilícitas. Correspondem a 29\% dos homicídios em Belo Horizonte (MG) e a 25\% em Maceió (AL). Corroboram a vertente teórica da criminologia nacional e internacional, que destaca o aspecto sistêmico da violência no mercado das drogas ilícitas. Os assassinatos estão relacionados à combinação de racionalidade econômica e ilegalidade que estruturam esse mercado. Corrobora-se, assim, a dimensão sistêmica da relação entre drogas e violência nos termos de Goldstein (1985).

Isso ocorre porque nos mercados ilegais os problemas de valor dos bens comercializados, da competição entre os fornecedores e da cooperação entre os atores econômicos apresentam dinâmicas específicas, distintas da dos mercados legais. Em outras palavras, a construção da ordem social nos mercados ilegais manifesta singularidades que os diferenciam dos mercados legais (Beckert, 2009).

A cooperação se torna o maior desafio dos mercados ilegais, dado que o Estado está ausente enquanto instituição garantidora de contratos. Desta forma, a confiança entre fornecedor e consumidor adquire maior importância nessas transações. Nesse contexto, a ameaça ou uso potencial da violência se torna um mecanismo de suporte da cooperação, e garantidor da ordem social, haja vista a impossibilidade de se recorrer ao Estado para garantir o devido cumprimento dos acordos (Beckert, 2013). 
Não se trata de afirmar que a violência constitui o padrão rotineiro de indução da cooperação entre os atores envolvidos no mercado ilegal das drogas. Mas ela pode ser acionada em contextos específicos, especialmente diante dos altos riscos da traição nos mercados ilegais. Sob tal perspectiva, o uso da força física se apresenta como instrumento racional de minimização dos riscos advindos dessas situações. A violência, então, é um recurso possível, que garante algum grau de previsibilidade na dinâmica dos negócios em caso da quebra dos contratos; ou seja, os atores envolvidos sabem dos altos custos advindos de uma traição ou descumprimento de ordens. Para isso, não há como desconsiderar a presença e uso das armas de fogo entre os traficantes como estratégia de afirmação de reputação perante concorrentes (eliminação de competição) e clientes (garantia de cumprimento do acordo).

Não é casual, portanto, a constatação de que a presença de armas de fogo é muito mais destacada nos homicídios motivados pelo comércio das drogas ilícitas comparativamente às demais motivações. Tanto em Belo Horizonte (MG) quanto em Maceió (AL), mais de 95\% dos eventos com essa motivação envolveram armas de fogo; ao passo que nas demais motivações a presença de armas de fogo ficou abaixo de $80 \%$.

Outra evidência empírica a ser destacada diz respeito ao incisivo viés de gênero nos homicídios motivados pelo comércio das drogas ilícitas. Tal viés também está explícito nas demais motivações em ambas as cidades. Contudo, a participação feminina como vítima e como autora nos homicídios do mercado das drogas é a metade da verificada nos homicídios por desentendimento, rivalidades e passionais. A violência associada ao mercado das drogas ilícitas é eminentemente protagonizada pelo gênero masculino, entre homens que matam outros homens.

\section{MERCADO DAS DROGAS ILÍCITAS E DIFUSÃO DA VIOLÊNCIA}

A despeito da maior participação percentual da motivação atinente ao mercado das drogas ilícitas, os patamares do fenômeno são bastante inferiores ao que é geralmente propagado por autoridades políticas e da segurança pública. Menos de $1 / 3$ dos homicídios se enquadram nesse tipo - tanto em Belo Horizonte (MG) quanto em Maceió (AL). A maioria absoluta dos casos se relaciona a conflitos passionais, desentendimentos e rivalidades. Tende-se a concluir, portanto, que a violência interpessoal que caracteriza as cidades estudadas está muito mais relacionada a um padrão moral pautado pela solução violenta 
de conflitos, do que propriamente a uma violência oriunda das drogas ilícitas. Sugere a prevalência de uma sociabilidade violenta (Machado da Silva, 2010).

Mas ao analisar em detalhes os homicídios decorrentes de conflitos passionais, vinganças, rivalidades, desentendimentos e outras motivações em geral, foi descoberta certa recorrência de autores dos crimes envolvidos com o comércio de drogas ilícitas, qualificados nos inquéritos como traficantes de drogas. Alguns casos ilustrativos estão explicitados adiante.

\section{Caso 1}

A vítima foi morta por BIEL com a ajuda de BRYAN e JACKSON. BRYAN e JACKSON chamaram a vítima para ir à casa de BIEL, fizeram que a vítima entrasse em um beco sem saída, e BIEL surgiu e matou a vítima a tiros. Segundo testemunhas a vitima e os agressores eram traficantes de drogas e muito amigos, porém BIEL teve sua motocicleta queimada e acreditava que a vítima tivesse feito isso. A vítima chegou a contar para a mãe que estava com muito medo de BIEL pois ele achava que a vitima tinha posto fogo na moto mas ele não tinha. A testemunha Jonathan afirmou que foi ele quem colocou fogo na moto (Belo Horizonte - IP /2012).

\section{Caso 2}

A vítima foi alvejada por disparos de arma de fogo em via pública pelo seu vizinho, conhecido como Negão. Segundo testemunhas, a vítima havia roubado uma caixa de som de Negão há três semanas. A família da vítima, tomando conhecimento e sabendo que a vítima era usuária de drogas, devolveu a caixa de som a Negão. A partir daí, Negão, que é conhecido como traficante na área, começou a ameaçar a vítima. E um dia, enquanto a vítima estava com amigos na rua, Negão atirou cinco vezes mas não feriu outras pessoas. Um primo da vítima que estava no local do crime disse que Negão atirou na vítima e correu, não sendo mais encontrado (Maceió - IP /2013).

\section{Caso 3}

A vítima namorava há cerca de 8 meses com uma garota que tinha envolvimento com o tráfico de drogas. A namorada da vítima também se relacionava amorosamente com o autor do crime, gerente de uma boca de tráfico, e seu 
primo. O autor tinha muito ciúme da namorada, tendo agredido a um exnamorado dela anteriormente. No dia do ocorrido, a vítima foi convidada pela namorada a ir a um culto em sua igreja, mas recusou. De acordo com depoimentos de testemunhas, a namorada insistiu muito para que a vítima a acompanhasse na igreja e a vítima, por fim, cedeu. Durante o culto, na frente de todos os presentes, o autor agrediu a vítima com coronhadas e disparou 3 vezes, fugindo em seguida. A namorada também desapareceu desde então, a polícia investiga a participação dela no crime (Belo Horizonte - IP /2013).

Caso 4

A vítima era moradora do bairro Virgem dos Pobres II e estava indo visitar a irmã no bairro Virgem dos Pobres III quando o traficante que domina a área atirou contra ele, que foi morto na hora. Segundo o próprio agressor ele sabia que a vítima era moradora de outro bairro dominado por outros traficantes e resolveu atirar nele pois a vítima o estava "encarando" (Maceió - IP/2013).

\section{Caso 5}

De acordo com declarações, a vítima estava bebendo em companhia do agressor, que a chamou para conversar fora do local. Em seguida foram ouvidos os disparos. A motivação seria o fato de o irmão do agressor ter-se envolvido em uma briga que a vítima teria separado, mas ameaçado todos envolvidos na cena. De acordo com declarações, os agressores são traficantes da região e têm como chefe "Barrinha" ou "Chefão", que encontra-se preso, e "Berg" $e$ "Dedo" também participam do grupo do Paredão. De acordo com declarações da família, a vítima não era envolvida com a criminalidade, era do Exército Brasileiro (Maceió - IP/2012).

\section{Caso 6}

A vítima foi alvejada por cinco tiros em via pública. Segundo a namorada da vitima, ele traficava drogas e foi morto porque era amigo de um traficante chamado PEQUENO. PEQUENO matou um homem (dono de um abatedouro) e o cunhado deste homem, Eduardo, matou PEQUENO. Ainda querendo vingança da morte do cunhado, EDUARDO matou a vítima e ameaçava matar a namorada da vítima. Uma mulher, testemunha ocular do crime, confirmou que EDUARDO matou a vítima. Tanto Eduardo, a vítima e Pequeno eram todos traficantes de drogas. EDUARDO foi indiciado (Maceió - IP/2013). 
Nenhum desses casos foi classificado no presente estudo como homicídio motivado por conflito no mercado das drogas ilícitas. Os casos 1 e 2 foram considerados homicídios motivados por rivalidades; o caso 3 constitui exemplo de homicídio motivado por conflitos passionais; o caso 5 foi considerado homicídio motivado por desentendimento; e no caso 6 prevaleceu a motivação por vingança. Já o caso 4, diante do caráter inusitado da justificativa dada pelo autor do homicídio, optei por enquadrá-lo em outras motivações.

Qualifiquei essas situações de homicídios como Motivações diversas com autores que atuam mercado das drogas ilícitas, distinguindo-as das Motivações diversas com autores que não atuam no mercado das drogas ilícitas. As tabelas 10 e 11 sistematizam os dados obtidos com essa nova forma de categorização, incluindo a motivação decorrente da dinâmica do mercado das drogas ilícitas. É possível constatar que a porcentagem dos homicídios direta e indiretamente relacionada ao comércio das drogas ilícitas aumenta substantivamente. Em Belo Horizonte (MG) cerca de 50\% dos casos enquadram-se nessa situação, ao passo que em Maceió (AL) o número é de 45\%.

Essas situações de homicídios, que envolvem a autoria de indivíduos que atuam como comerciantes de drogas ilícitas, devem ser compreendidas como manifestações de um fenômeno social que qualifico como difusão da violência pelo mercado das drogas ilícitas. Os homicídios não resultam apenas de conflitos decorrentes da dinâmica da atividade comercial. Os agentes econômicos, que são os vendedores das drogas ilícitas, tendem a utilizar a violência física como mecanismo de imposição de suas vontades nos mais diversos tipos de conflitos nos quais se envolvem nos territórios onde atuam comercialmente. Nas relações afetivas, nas relações familiares, nas relações de vizinhança e na sociabilidade cotidiana, os comerciantes das drogas ilícitas tendem a utilizar o mesmo padrão violento de resolução de conflitos vivenciado nas relações estritamente econômicas com parceiros de negócios, com concorrentes, com fornecedores e com clientes. E a posse de armas de fogo é elemento decisivo nesse fenômeno. 
Tabela 10

Tipo de Motivação do Homicídio Combinado com o Tipo de Participação do Autor no Mercado das Drogas Ilícitas - Belo Horizonte (MG)

\begin{tabular}{lll}
\hline Motivação & $\mathrm{N}$ & $\%$ \\
\hline Mercado das drogas ilícitas & 57 & 29 \\
Diversas com autores que atuam no mercado das drogas ilícitas & 41 & 21 \\
$\begin{array}{l}\text { Diversas com autores que não atuam no mercado das drogas } \\
\text { ilícitas }\end{array}$ & 96 & 50 \\
\hline Total & 194 & 100 \\
\hline
\end{tabular}

Fonte: Inquéritos policiais de homicídios com autoria identificada. Elaboração própria.

Tabela 11

Tipo de Motivação do Homicídio Combinado com o Tipo de Participação do Autor no Mercado das Drogas Ilícitas - Maceió (AL)

\begin{tabular}{lll}
\hline Motivação & N & $\%$ \\
\hline Mercado das drogas ilícitas & 75 & 25 \\
Diversas com autores que atuam no mercado das drogas ilícitas & 61 & 20 \\
$\begin{array}{l}\text { Diversas com autores que não atuam no mercado das drogas } \\
\text { ilícitas }\end{array}$ & 165 & 55 \\
\hline Total & 301 & 100 \\
\hline Fonte: Inquéritos policiais de homicídios com autoria identificada. Elaboração própria.
\end{tabular}

Não se trata de difusão da violência para as inúmeras relações sociais nos territórios onde funciona o comércio das drogas ilícitas. As evidências obtidas não permitem afirmar que os moradores do território como um todo tendem a se tornar mais violentos na resolução de seus conflitos cotidianos. São os indivíduos que comercializam as drogas que tendem a usar intensivamente armas de fogo na resolução dos mesmos. Eles se tornam protagonistas da violência interpessoal nos territórios onde atuam comercialmente. Pode-se afirmar que se destacam como portadores de uma sociabilidade violenta (Machado da Silva, 2010). E fazem isso porque estão imbuídos de um etos da masculinidade, da virilidade e da afirmação da força física, adquiridos na dinâmica do mercado ilícito das drogas (Zaluar, 2012). 


\section{CONSIDERAÇÕES FINAIS}

As conclusões desta pesquisa devem ser matizadas devido à abrangência restrita das bases empíricas tanto no tempo quanto no espaço. Entretanto, as situações dos homicídios em Belo Horizonte (MG) e em Maceió (AL)- cidades situadas em contextos regionais diferenciados -, reforçam a hipótese de que o mercado das drogas ilícitas se consolidou como relevante matriz da violência interpessoal na sociedade brasileira.

É fato que existem diferenças relevantes na conformação do fenômeno nas respectivas cidades. Os homicídios passionais são proporcionalmente mais frequentes em Belo Horizonte (MG), ao passo que na capital alagoana os homicídios derivados de desentendimentos e de rivalidades são mais rotineiros. Isso certamente diz muito acerca das características do processo (des)civilizador prevalecente em ambos os contextos urbanos.

A participação da Polícia no fenômeno, por sua vez, ficou bem abaixo das realidades do Rio de Janeiro (RJ) e de São Paulo (SP). Contudo, se considerarmos os dados divulgados pelo FBSP, há convergência entre os dados encontrados pelos dois estudos. No Anuário Brasileiro de Segurança Pública de 2014 (Anuário, 2014), a letalidade policial no estado de Alagoas ficou no patamar de 1,3\%, e no estado de Minas Gerais foi de 1,2\%. Esses números são inferiores, inclusive, aos encontrados por esta pesquisa nas capitais desses estados. É pertinente supor a subnotificação desse tipo de motivação no material analisado. Isso porque nos homicídios cometidos por policiais em serviço, a autoria é sempre identificada, mas o policial muito raramente é indiciado por contar com a "exclusão de ilicitude", sendo classificados como "autos de resistência", e não como homicídios (Misse, Grillo e Neri, 2015).

Reforço também a constatação de que a violência associada à dinâmica do mercado das drogas ilícitas espraia-se para além das relações estritamente econômicas. $\mathrm{O}$ etos da masculinidade e da virilidade, tão constitutivo desse mercado ilícito, como mostra Alba Zaluar (2012), é reafirmado em outros conflitos vivenciados pelos atores. Esse fato coaduna-se com os achados de Rocha (2015) e de Zilli e Beato (2015), que defendem a importância dos ciclos de vingança para a devida compreensão de diversos homicídios entre jovens membros de gangues residentes em territórios de alta vulnerabilidade social na cidade de 
Belo Horizonte (MG). Trata-se, sob meu ponto de vista, da manifestação do fenômeno que denomino de difusão da violência pelo mercado das drogas ilícitas.

Devemos considerar, contudo, que a relação entre mercado das drogas ilícitas e homicídios é mediatizada pelo território onde se desenrolam as trocas econômicas. Conforme análise de Carolina Grillo (2008; 2013), há o "tráfico de drogas do morro" e o "tráfico de drogas da pista" sendo que no primeiro caso, as redes de comercialização ocorrem em regiões de maior vulnerabilidade social, e no segundo, prevalecem redes de comercialização em regiões de classes médias. Notoriamente, os homicídios são muito mais frequentes no "tráfico do morro".

Em estudo anterior identifiquei o mesmo fenômeno na cidade de Belo Horizonte (MG) (Sapori,Lamounier e Silva, 2012). Há dois formatos distintos de redes no varejo das drogas ilícitas na cidade, denominadas de redes de bocas e redes de empreendedores. A rede de empreendedores é uma estrutura descentralizada, que tem como referência central hiperlinks, que são referências conectoras de uma rede de comercialização de drogas. A dinâmica dessa rede se configura por um conjunto de nós interligados a esse hiperlink, o empreendedor, com o objetivo inicial de obter o produto por ele comercializado. Esse acesso ocorre através de um sistema de referência mediado, principalmente, por relacionamentos com grupos de amigos ou indicações. Os hiperlinks atuam de maneira relativamente autônoma em relação às estruturas mais ampliadas de produção e/ou distribuição de drogas. Entretanto, a rede de empreendedores não é desprovida de uma estrutura mais centralizadora, qualificada de Firma. A posição de comando central da Firma é conhecida por gerente, sendo responsável pelo gerenciamento da sua rede de conexões. O empreendedor não se posiciona como um empregado da Firma, mas como quem mantém com ela um relacionamento comercial, pois é a fonte fornecedora do produto comercializado. Nesse tipo de rede de comercialização, a incidência de homicídios é praticamente inexistente. Ela prevalece nos bairros com população residente de maior poder aquisitivo.

Boca, por sua vez, é referência de um espaço físico, constituindo-se como ponto comercial para a venda de uma droga ilícita. É o lugar, e não os indivíduos, que atua como hiperlink para a formação das conexões. Constitui rede de comercialização hierarquicamente centralizada, uma Firma, reconhecida como pertencente a um patrão. 
Apresenta estrutura hierárquica de poder e divisão de atividades de trabalho. O patrão é aquele que "põe a droga no lugar". Não é necessariamente morador local e pode ser proprietário de uma ou mais bocas em locais distintos. Em geral, não é conhecido pelos pequenos traficantes que trabalham diretamente conectados a essa estrutura. Seu contato é mais restrito ao gerente. O gerente é conexão central na rede de bocas. Seu papel é de grande responsabilidade e com atividades multivariadas. Encarrega-se do embalo, distribuição da mercadoria, contagem, aferição de lucro, distribuição de tarefas, decisão sobre a forma de resolução dos problemas. acertos de contas, e administração dos recursos humanos.

Um dos movimentos mais dinamizadores de uma rede de bocas é o das conexões dos jovens locais que querem se integrar à linha de frente da comercialização. Podem estar conectados na condição de vapores ou guerreiros (vendedores), aviões (acionam os vendedores e entregam a droga), correria (deslocamento entre bocas), olheiros, fogueteiros (acionadores da segurança), faxineiros ou ratos (cobradores e matadores). É nesse segmento da rede de bocas que se inserem as gangues juvenis, nos bairros mais empobrecidos da cidade, e mais susceptíveis à violência interpessoal.

Finalizo destacando a implicação dessa pesquisa para as políticas de segurança pública no Brasil. O mercado das drogas ilícitas é uma das matrizes da nossa violência urbana, conforme já mencionei. Mas isso não significa que essa violência seja inevitável ou que não possa ser contida. É possível, mediante a adoção de ações repressivas e preventivas consistentes, reduzir substantivamente a incidência dos homicídios provenientes desse mercado ilícito nos territórios de maior vulnerabilidade social. Experiências internacionais e mesmo nacionais são reveladoras nesse sentido. A diretriz da política de segurança pública não deve ser o confronto armado com o tráfico de drogas. Tende a ser mais efetiva a diretriz da redução da violência associada a esse mercado ilícito. E a repressão qualificada, focada na identificação e prisão dos protagonistas dos homicídios nos territórios onde atuam, tende a gerar resultados mais satisfatórios na contenção do processo de difusão da violência.

Soma-se a isso a potencialidade da implementação de projetos de prevenção social da criminalidade. Não basta investigar, processar, condenar e prender jovens envolvidos com o tráfico de drogas, e que 
são portadores de sociabilidade violenta (Machado da Silva, 2010). Somente punir, não resolve. A prevenção social é outra diretriz de política de segurança pública que deve ser priorizada. E, para tanto, é preciso focar nos fatores de risco que incrementam as chances de crianças e, especialmente adolescentes, de serem cooptados pelo tráfico de drogas. As iniciativas que já se revelaram eficazes nesse sentido, como o projeto FICA VIVO, em Minas Gerais, combinam focalização territorial e do público-alvo, mobilização comunitária, parceria com organizações não governamentais e articulação com o aparato policial. Tão importante quanto impor custos ao uso da violência por parte dos jovens do tráfico de drogas é propiciar a jovens residentes em territórios de elevada vulnerabilidade social oportunidades de construírem suas trajetórias de vida por vias que não sejam as do mundo do crime.

(Recebido para publicação em 9 de agosto de 2018)

(Reapresentado em 27 de agosto de 2019) (Aprovado para publicação em 5 de novembro de 2019)

\section{NOTAS}

1. https://g1.globo.com/monitor-da-violencia/noticia/brasil-registra-quase-60-mil-pessoas-assassinadas-em-2017.ghtml; https://www.gazetadopovo.com.br/especiais/ paz-tem-voz/droga-causa-77-dos-homicidios-9dgb4ldc3wfdvvkce6rztqtzi/; https:/ /cidadeverde.com/noticias/274931/90-dos-crimes-de-homicidios-tem-relacao-direta-com-as-drogas-diz-baretta

2. A pesquisa foi financiada em parte pela Fundação de Amparo à Pesquisa do Estado de Minas Gerais - FAPEMIG. 


\section{REFERÊNCIAS}

ANUÁRIO Brasileiro de Segurança Pública. (2014), Fórum Brasileiro de Segurança Pública. São Paulo.

BEATO, Claudio et al. (2001), "Conglomerados de homicídios e o tráfico de drogas em Belo Horizonte, Minas Gerais, Brasil, de 1995 a 1999". Cad. Saúde Pública, Rio de Janeiro, 17(5), pp. 1163-1171.

BECKERT, Jens. (2009), "The social order of markets". Theory and Society, n. 38, pp. 245-269.

BECKERT, Jens; WEHINGER, Frank. (2013), "In the shadow: ilegal markets and economic sociology". Socioeconomic Reviewn. 1, v. 11, pp. 5-30.

BLUMSTEIN, Alfred (1995), "Youth violence, guns and the illicit drug industry". The Journal of criminal law Ecriminology, v. 86, n. 1., pp. 10-36

BOYUM, David et al. (2011), "Drugs, crime and public policy" in WILSON, James, PETERSILIA, Joan (eds): Crime and public policy. New York. Oxford University Press.

CANO, Ignácio; SANTOS, Nilton. (2001), Violência letal, renda e desigualdade social no Brasil. Rio de Janeiro. 7 Letras.

CARDIA, Nancy; ADORNO, Sérgio; POLETO, Frederico. (2003), “Homicídio e violação de direitos humanos em São Paulo". Estudos Avançados, v. 17, n. 47, pp. 43-73.

CERQUEIRA, Daniel et alii. (2017), Atlas da Violência 2017. IPEA e FBSP. Rio de Janeiro.

FELTRAN, Gabriel. (2010), “Crime e castigo na cidade: os repertórios da justiça e a questão do homicídio nas periferias de são paulo". Caderno $C R H$, salvador, v. 23, n. 58, pp. 59-73.

COSTA, Arthur Trindade. (2011), Violências e conflitos intersubjetivos no Brasil contemporâneo. Caderno CRH, Salvador, v. 24, n. 62, pp. 353-365.

GOLDSTEIN, Paul (1985), "The drugs/violence nexus: a tripartite conceptual framework". Journal of drugs issues, v. 15, n. 4, pp. 493-506.

GRILLO, Carolina Christoph. (2008), “O 'morro' e a 'pista': Um estudo comparado dedinâmicas do comércio ilegal de drogas". Dilemas: Revista de Estudos de Conflito e Controle Social. Rio de Janeiro, v. 1, n. 1. pp. 127-48.

(2013), Coisas da vida no crime: tráfico e roubo em favelas cariocas. Rio de Janeiro, tese de doutorado, Programa de Pós-graduação em Sociologia e Antropologia da Universidade Federal do Rio de Janeiro.

(2016), "Fronteiras tácitas: confronto e acordo em favelas do Rio de Janeiro". Confins: Revista Franco-Brasileira de Geografia, 28: [s.p.]. Disponível em https://confins.revues. org $/ 11246$.

JOHNSON, Bruce; GOLUB, Andrew; DUNLAP, Eloise (2000). "The rise and decline of hard drugs, drugs markets and violence in inner-City New York", in BLUMSTEIN, A.; WALLMAN, J. The crime drop in America. New York, Cambridge University Press, pp. 164-76

KANT DE LIMA, Roberto (1994), A Polícia da Cidade do Rio de Janeiro. Seus dilemas e paradoxos. Rio de Janeiro: Forense Universitária. 


\section{Luís Flávio Sapori}

MACHADO DA SILVA, Luiz Antônio. (2010), Violência urbana, segurança pública e favela - o caso do Rio de Janeiro atual. Caderno CRH, Salvador, v. 23, n. 59, pp. 283-300.

MIETHE, Terance; REGOECZI, Wendy. (2004), Rethinking homicide: exploring structure and process underlying deadly situations. Cambridge (UK). Cambridge University Press.

MISSE, Michel. (1999), Malandros, marginais e vagabundos e a acumulação social da violência no Rio de Janeiro. Rio de Janeiro, Tese (Doutorado em Sociologia) - Instituto Universitário de Pesquisas do Rio de Janeiro.

. (2006), Crime e violência no Brasil contemporâneo. Estudos de sociologia do crime e da violência urbana. Rio de Janeiro: Lúmen Juris.

. (2007), Mercados ilegais, redes de proteção e organização local do crime no Rio de Janeiro. Estudos Avançados v. 21, n. 61, pp. 139-156.

. (2011), O papel do inquérito policial no processo de incriminação no Brasil: algumas reflexões a partir de uma pesquisa. Revista Sociedade e Estado, v. 26, n. 1, pp. 15-27.

MISSE, Michel; GRILLO, Carolina; NERI, Natasha E. (2015), Letalidade policial e indiferença legal: A apuração judiciária dos 'autos de resistência' no Rio de Janeiro (2001-2011). Dilemas, Edição Especial, n. 1. pp. 43-71.

NOBREGA JÚNIOR, José Maria Pereira. (2016), “Índice de Desenvolvimento Humano e a violência no Nordeste: o paradoxo nordestino". Revista Espaço Acadêmico, 182, pp. 56-72

PERES, Maria Fernanda T. et al. (2011), “Queda dos homicídios no Município de São Paulo: uma análise exploratória de possíveis condicionantes". Revista Brasileira de Epidemiologia, v. 14, n. 4 , pp. 709-21.

RATTON, Jose Luiz; DAUDELIN, Jean. (2017), "Mercados de drogas, guerra e paz no Recife". Tempo Social, v. 29, n. 2, pp. 115-133.

ROCHA, Rafael Lacerda. (2015), “A guerra como forma de relação: Uma análise das rivalidades violentas entre gangues em um aglomerado de Belo Horizonte". Dilemas, v. 8, n. 2, pp. 277-301.

SAPORI, Luis Flavio; MEDEIROS, Regina. (2010), Crack, um desafio social. Belo Horizonte. Editora Puc Minas.

SAPORI, Luis Flavio; LAMOUNIER, Lucia; SILVA, Braulio F. (2012), "Mercado do crack e violência urbana na cidade de Belo Horizonte". Dilemas, v. 5, n. 1, pp. 37-66.

SAPORI, Luis Flávio, SOARES, Gláucio Ary Dillon. (2014), Por que cresce a violência no Brasil? Belo Horizonte. Editora Autêntica. Editora PUC Minas.

SILVA, Klarissa Almeida. (2008), Tipologia de homicídios: uma análise sociológica das denúncias oferecidas pelo Ministério Público de Minas Gerais. Revista Brasileira de Ciências Criminais. IBCCRIM. n. 74, setembro/outubro, pp. 339-360.

SIMMEL, Georg. (1983), Georg Simmel: sociologia. Evaristo de Moraes Filho (org.), São Paulo, Ática.

SOARES, Gláucio. (2008), Não matarás. Rio de Janeiro, Fundação Getúlio Vargas.

SOARES, Luiz Eduardo. (2006), Segurança pública: presente e futuro. Estudos Avançados, v. 20, n. 56, pp. 91-106.

DADOS, Rio de Janeiro, vol.63(4): e20180191, 2020. 
TELLES, Vera da Silva; HIRATA, Daniel. (2007), “Cidade e práticas urbanas: nas fronteiras incertas entre o ilegal, o informal e o ilícito". Estudos Avançados, v. 21, n. 61, pp. 173-191.

TONRY, Michael; WILSON, James (1990). Drugs and crime. Crime and Justice. A Review of Research. Chicado and London. The University of Chicado Press.

VARGAS, Joana Domingues (2007), “Análise comparada do fluxo do sistema de justiça para o crime de estupro". Dados, v. 50, n. 4, pp. 671-698.

WAISELFISZ, Julio Jacobo. (2016), Mapa da violência. Homicídios por armas de fogo no Brasil. FLACSO Brasil, Rio de Janeiro.

WILSON, James; PETERSILIA, Joan (2011), Crime and public policy. New York. Oxford University Press.

ZALUAR, Alba. (1985), A Máquina e a Revolta. Rio de Janeiro, Brasiliense. (1994), Condomínio do Diabo. Rio de Janeiro, Ed. UFRJ. (2004), Integração Perversa: Pobreza e Tráfico de Drogas. Rio de Janeiro, Editora FGV. . (2012), Juventude violenta: processos, retrocessos e novos recursos. Dados, v. 55, n. 2, pp. 325-364.

ZILLI, Felipe; BEATO, Claudio. (2015), “Gangues juvenis, grupos armados e estruturação de atividades criminosas na Região Metropolitana de Belo Horizonte". Dilemas, Edição Especial, n. 1, pp. 73-110. 


\section{RESUMO}

Mercado das Drogas Ilícitas e Homicídios no Brasil: Um Estudo Comparativo das Cidades de Belo Horizonte (MG) e Maceió (AL)

Esse artigo analisa o impacto do mercado das drogas ilícitas na incidência de homicídios em Belo Horizonte (BH) e Maceió (AL). Foram consultados os relatórios finais dos inquéritos policiais de homicídios com autoria identificada nas respectivas cidades, no biênio 2012-2013. Elaborou-se uma tipologia de motivações de homicídios a partir da qual procedeu-se à categorização de cada caso. A principal descoberta da pesquisa é a constatação de que o mercado das drogas ilícitas é motivação relevante dos homicídios em ambas as cidades. Porém, em magnitude inferior à geralmente propagada por autoridades da segurança pública. Identificou-se também um número expressivo de homicídios cuja motivação não era relacionada à dinâmica do mercado das drogas ilícitas, mas cujos autores tinham envolvimento com essa atividade criminosa. Esse fenômeno foi denominado de difusão da violência pelo mercado das drogas ilícitas.

Palavras-chave: homicídio; drogas; violência; mercado ilícito; tráfico de drogas

\section{ABSTRACT \\ The Market for Illicit Drugs and Homicide in Brazil: A Comparative Study of the Cities of Belo Horizonte (MG) and Maceió (AL)}

This article analyzes the impact of the illicit drug market on the incidence of homicides in the cities of Belo Horizonte (MG) and Maceió (AL). The final reports of police investigations of homicides whose authorship was identified in the respective cities in the 2012-2013 biennium were consulted. A typology of homicide motivations was elaborated, from which each case was categorized. The main finding of this research is that the illicit drug market is a relevant motivation for homicides in both cities. However, this correlation has a lower magnitude than what is generally propagated by public security authorities. A significant number of homicides whose motivation was not related to the dynamics of the illicit drug market, but whose authors were involved in this type of criminal activity, were also identified. This phenomenon was called the spread of violence through the illicit drug market.

Keywords: homicide; drugs; violence; illicit market; drug trafficking 


\section{RÉSUMÉ}

Marché des Drogues Illicites et des Homicides au Brésil: Une Étude Comparative des Villes de Belo Horizonte (MG) et Maceió (AL)

Cet article analyse l'impact du marché des drogues illicites sur l'incidence des homicides à Belo Horizonte (MG) et Maceió (AL). Les rapports finaux des enquêtes policières sur les homicides avec culpabilité conclu dans les villes respectives au cours de l'exercice biennal 2012-2013 ont été consultés. Une typologie des motivations d'homicide a été élaborée à partir de laquelle chaque cas a été classé. La principale conclusion de la recherche est la constatation que le marché des drogues illicites est une motivation pertinente pour les homicides dans les deux villes. Cependant, dans une moindre mesure que ce qui est généralement diffusé par les responsables de la sécurité publique. Un nombre important d'homicides ont également été identifiés dont la motivation n'était pas liée à la dynamique du marché des drogues illicites, mais dont les auteurs étaient impliqués dans cette activité criminelle. Ce phénomène était appelé la propagation de la violence par le marché des drogues illicites.

Mots-clés: homicide; drogue; violence; marché illicite; trafic de drogue

\section{RESUMEN}

Mercado de las Drogas Ilícitas y Homicidios en Brasil: Un Estudio Comparado de las Ciudades de Belo Horizonte (MG) y Maceió (AL)

Este artículo analiza el impacto del mercado de las drogas ilícitas en la incidencia de homicidios en Belo Horizonte (BH) y Maceió (AL). Fueron consultados los informes finales de las investigaciones policiales de homicidios, con autoría identificada en las respectivas ciudades, en el bienio 2012-2013. Se elaboró una tipología de motivaciones de homicidios a partir de la cual se procedió a la categorización de cada caso. El principal hallazgo de la investigación es la constatación de que el mercado de las drogas ilícitas constituye una motivación relevante para los homicidios en ambas ciudades. Sin embargo, en menor magnitud a la generalmente propagada por autoridades de seguridad pública. Se identificó también un número expresivo de homicidios cuya motivación no estaba relacionada con la dinámica del mercado de las drogas ilícitas, pero cuyos autores estaban involucrados con esa actividad criminal. Ese fenómeno fue denominado como difusión de la violencia por el mercado de las drogas ilícitas.

Palabras clave: homicidio; drogas; violência; mercado ilícito; tráfico de drogas 